- Kitap İncelemeleri.Book Reviezus-

\title{
Tschumi'de Olay, Mimaride Kopma, Sinemada Benlik
}

\author{
İnceleyen: Beste Çırak
}

\begin{abstract}
Kopma: bir bağın kopması ya da bağdan kopmuş olma; ayrılma, birliğin bozulması. Bir ayrık önermenin terimleri arasındaki bağıntı.
\end{abstract}

-Webster's Dictionary (akt. Tschumi, 2017, s.11)

Tschumi, Mimarlık ve Kopma'ya bu tanımlamayla başlıyor. Mekan ile mekanı kullanımın elle tutulabilir bir bağlantısının artık kalmadığını savunan Tschumi, mekandaki kopmaların sürekli gerçekleştiğini ve bu durumun mimarın kontrolünden çıktığını söylemektedir. Yapının gövdesi ve kullanımı arasındaki bağ, giderek gücünü kaybetmektedir. Salt radikal aklın erişemediği olasılıktaki kopmalar, modern kutular tarafından zapt edilmeye çalışılmakta ve başarısız olunmaktadır. İstikrarlı ve sağlam olduğunu varsaydığımız bu kutu mimarisi, ittire ittire içine sığdırdı ğı hayatların; tüm eylem ve tacizlerine sahne olmakta, kopma giderek belirginleşmektedir. ABD'nin Missouri eyaletindeki St. Louis'de 1955 yılında tamamlanan Pruitt-Igoe projesi bu kopmanın en belirgin örneklerindendir. Dönemin demokratik Belediye Başkanı Joseph Darst 1951' de bir konuşmasında “Kentlerimizin kalbini yeniden inşa etmeli, açmalı ve temizlemeliyiz. Gerçek şu ki varoşların bütün belaları herkesin hatasıyla yaratıldı. Şimdi zararını düzeltmek de herkesin sorumluluğu." derken; varoşlara soyluluk, kentin doğusuna barış götürmeyi hedeflemekteydi. "Fakir insanlar için dikey mahalleler" vaat eden ve 33 adet 11 katlı apartmandan oluşan bu toplu konut projesi (Ek A); rrkçı suçların ve çete savaşlarının merkezi haline geldi. Suç oranının tavan yaptığı kentte; apartmanlar aynı irade tarafından tek tek yıkıldı (Ek B). Yapının mimarı Minoru Yamasaki “İnsanların bu kadar yıkıcı olduğunu hiç düşünmemiştim" (Koyuncu, 2011) derken ise mimariyi putlaştırmakta ve insan, toplum, devlet ve ekonomi ile olan sosyal ilişkilerini yok sayarak; kopmanın asıl sebebini yeniden üretmektedir.

Mimarlığın Paradoksu bölümünde Descartes'la birlikte mekanın, Aristotelesçi geleneğin kategorilerinden sıyrılıp mutlaklaştı̆̆ını yazan Tschumi; "özneden önce gelen nesne olarak mekan, duyulara ve gövdelere onları kapsayarak egemen oldu" diye ekliyor (Tschumi, 2017, s.44). Aynı zamanda Mekanın Sınırları bölümünde de mekanın bedene ve bedenin mekana koyduğu sınırları, ihlallerini ve yeniden sunumunu tartışıyor. 1978 yılında yayınladığı Advertisements for Architecture serisinin bir parçası olan afişte (Ek C), mimarinin tanık olduğu eylemlerle olduğu kadar duvarlarının çevrelemesiyle de tanımlandığı söyleyen Tschumi; sokakta işlenen bir cinayet ile katedralde işlenen bir cinayetin tamamen farklı anlamlara geldiğini vurguluyor. Nesne olarak mekan, olayın işleyişine ve anlamına doğrudan müdahalede bulunuyor. Bad Lieutenant'ta (Kötü Polis, Abel Ferrara, 1992) gördügüümüz rahibe ile I Spit on Your Grave' de (Mezarına Tüküreceğim, Meir Zarchi, 1978) gördüğümüz iki genç kadının, yaşadıkları aynı olay üzerine verdikleri tepkiler ve gelişen olaylar; kuşkusuz Tschumi' nin bu yorumunu doğrulamaktadır. Bad Lieutenant'ta kilisede tecavüze uğrayan rahibe, Tanrı'nın affediciliğine ve iyiliğin kibrine sığınarak genç, siyahi ve erkek tecavüzcülerini affederken; I Spit on Your Grave'de gördüğümüz doğada avlanan bir grup erkeğin tecavüzüne uğrayan 
genç kadın yazar, doğa-kültür ve kadın-erkek karşıtlıklarından sıyrılıp tüm tecavüzcülerini tek tek iğdiş eder. Doğayı ve kendini özgürleştirir.

Lastik, beton ve et kokusu her tarafı kaplar; tozun tadı; bir dirsek aşındırıcı bir yüzeye sürtülür, rahatsızca; kürk kaplı duvarların verdiği zevk ve karanlıkta bir köşenin verdiği ac1... Program bölümünde Tschumi, mekanı tanımlarken yalnızca zihnimizdeki bu yeniden sunumların üç boyutlu hali olmadığını; aynı zamanda işitilen ve eylemlerle karşılık verilen bir mekandan bahsediyor. Duyuların mekanı dediği bu mekanlarda insan, sadece hareket etmekle kalmıyor, hareketleriyle yeni mekanları da ortaya çıkarıyor. Gözün çerçevelediği mekanlar (pencere, kapı vb.) ve hareket mekanları (koridor, merdiven vb.); duyuların mekanıyla, toplumun mekanı arası eklemlenme (Tschumi, 2017, s.148). Repulsion'da (Tiksinti, Roman Polanski, 1965) Carole'un halüsinasyonlarında gördüğümüz hamurlaşmış ve içinden eller çıan koridor duvarları (Ek D); Carole'u içine saplandığı duyular dünyasına daha da çekmekte ve toplum mekanından onu uzak tutmaktadır. Babasının tacizine uğrayan Carole için ev, hem tüm tekinsizliklerin mekanı hem de en büyük sırdaşıdır. Rosemary's Baby'de (Rosemary'nin Bebeği, Roman Polanski, 1963) ise gizli bir kapı, sıradan görünenin şeytansılığına açllıyor. Gözün çerçevelediği bu mekan, bir dolaba saklanarak; mekan olarak varlığını yineliyor ve duyuların mekanına açılıyor. Toplumun sıradan ve uyumlanmış ideal bireyleri, gözün çerçevesinden çıktığında şeytani bir ayinin parçası haline geliyor.

Eylem olmadan mimarlık olmaz, olay olmadan mimarlık olmaz, program olmadan mimarlık olmaz.

Bu sözlerin kapsamını genişletirsek, şiddet olmadan mimarlık olmaz

Mimarlığın Şiddeti bölümüne bu iki maddeyle başlayan Tschumi, bir bina ve kullanıcıları arasındaki her ilişkinin bir şiddet ilişkisi olduğunu söyler. Mekanı her kullanım, bir düzenin diğer düzene sokulması anlamına gelmektedir. (Tschumi, 2017, s.161 - 162). Bu bağlamda şiddet kaçınılmazdır ve mekan doğası gereği şiddete meyillidir. Herhangi bir mekanın salt varlığ1, ilk olarak hacmini dayatmakta ve sinırlar çizmektedir. Daha sonra kullanım şemalarıyla emirler yağdırmaktadır. Cube (Küp, Ernie Barbarash \& Andrzej Sekuła \& Vincenzo Natali) serisi, mekanın bedene uyguladığ1 şiddetin en belirgin örneklerindendir. Birçok küpün birleşmesinden oluşan mega küpteki; sürekli yeni bir küpe çıkan kapıların ardında, her küpün kendine has dayatmaları vardır. Hayatta kalmak için mekanın şiddetine boyun eğmek ve kurallarına tabii olmak gerekmektedir. Dev bir oyun alanı olan küp, hem kendi varlığındaki bilinmezlikle hem de somut olarak sahip olduğu silahlarla, bedenler üzerinde çok katmanlı bir şiddet uygulamaktadır. Bedenin mekana yönelik şiddetini de tartışan Tschumi, bedenin; sadece orada olmakla bile mekana bir şiddet uyguladığını söyler. Bir binaya girmek bile, o binanın sahip olduğu keskin düzeni ve geometriyi bozarak mekanı taciz edecektir. Bedenlerin sürekli olarak öngörülemeyen bir biçimde yeni mekanlar oyduğunu ifade eden Tschumi, bedeni tehlikeli bir yasaklamaya eş değer bulur. Bedenin mimari düşüncenin saflığını bozduğunu düşünür. İnsan bedeninin sinırları, mimariye de sinırlar koyar (Tschumi, 2017, s.163). The Shining'teki (Cinnet, Stanley Kubrick, 1980) şık ve görkemli Overlook Oteli'nin kusursuz merdivenlerinde elinde bıçakla koşan hatta kapılarını baltayla parçalayan ve keskin bir düzene sahip labirentin içine dalarak tüm simetrisini alt üst etmek; bedenin mekanın saflığını bozarak uyguladığ tür şiddettir. His House (Onun Evi, Remi Weekes, 2020) filmindeki onlarca mültecinin küçük bir şişme bota sığmaya çalışması ise hem bedenlerin mekana uyguladığı, hem de mekanın bedenlere uyguladı̆̆ karşılıklı bir şiddettir. Bedenleri daracık bir alana sıkışmak zorunda bırakan mekan, kendi üstünlüğünü kurmaya çalışmakta; bedenler ise tüm ağırlığıyla mekanı eğip bükerek kendi varlığını dayatmaktadır. Nitekim mültecilerin bedenlerine o botta yer olmadığ 1 gibi o dünyada da yer yoktur. Kendilerine yaşayacak bir yer ya da sıkışacak bir mekan bulmaları için gelişen dünyaya ayak uydurarak insanlıktan çıkmaları gerekmektedir. 
Birbirinden bağımsız olarak var olan eylemlerin ve mekanların, birbiriyle kesiştiklerinde, birbirlerini etkilediğini söyleyen Tschumi; eylemlerin mekanlar tarafından nitelenmesi gibi, mekanlar da eylemler tarafından nitelenir der. Bu bağlamda Kuleşov Deneyi'nden (Lev Kuleşov, 1910) bahseden Tschumi, deneyde peş peşe gelen görüntülerin anlamı değiştirdiği gibi; her yeni mekanın da olayı değiştirdiği ya da her yeni olayın mekanı değiştirdiğini ifade eder (Tschumi, 2017, s.172). Visages Villages'te (Mekanlar ve Yüzler, Agnes Varda \& JR, 2017) bir kasabada, şehirde ve köyde mekanları yeniden niteleyen olaylar olan baskılar; mekanın tüm kimliğini yeniden inşa etmekte ve tüm heybetiyle dümdüz duran mekanı, insanlarla göz göze getirmektedir. Mekanın bu yeniden sunumu, onunla tekrar tanışmayı zorunlu kılacaktır. Gözetleme Kulesi'nde (Pelin Esmer, 2012) ise kule, Nihat'1 sürekli kontrolü altında hissettiği toplumdan soyutlayarak; kendisine sorular sormayan ve yargılamayan ağaçlar hariç her şeyden uzak tutuyor. Nihat'ı özgür kılan kule, onu gözetlenenden gözetleyene dönüştürüyor.

Mekanlar ve Olaylar bölümünde Tschumi, modernizmden post-modernizme geçildiği 1970'li yıllarda; bir bilgi biçimi olarak mimarlığın öneminin azalıp, bir biçim olarak mimarlığın öneminin arttığını söyler. Mimarlık; mekanlarla olaylar arasındaki çatışmalı ilişkiden kopartılıp, bir yüzey göstergeleri sistemine indirgenmiştir. Yüzeydeki göstergelerin estetiğine kendini kaptıran mimarların, mekânsal ve programatik meseleleri dışladığını belirten Tschumi; mimarlığın yalnızca seyredilecek bir şey halini alarak, mekan ve eylemlerin karşılıklı ilişkisini yok saydığını söyler. Bu tabloya karşın aynı dönemde öğrenciler, sözel olan ile görsel olan arasındaki diyalektik ilişkiyi keşfetmişlerdi. Yapılan fotokolajlarla disiplinler bir araya getiriliyor, sözcükler ve mekanlar arasındaki bir tür bağıntı açığa çıkıyordu. Anlatı sekansları ile mekânsal sekanslar arası kurulan paralellik, olayların mimari dâhilinde serimlenmesine yol açmıştı (Tschumi, 2017, s.183 - 191). Bu bağlamda hareket ile mekan, insan ile nesne ve biçim ile kullanım arasındaki çatışmalar yeniden ortaya koyuldu. Mekanın, hareketin ve olayın bağımsızlığından fakat oldukça sık olan kesişmelerinden yeni bir yol bulan Tschumi, Manhattan Transkriptleri'nde (Ek E) alışılmadık bir mimari anlatım kullandı. Olay, hareket ve mekan arasındaki karşılıklı çatışmaların güçlenerek, farklı anlatım olanakları bulduğu Transkriptler; Tschumi'nin deyimiyle, kendini tamamladı. Kentin yapı sökümünü yapmakla başladı ve yeni birleşim kodları keşfediyor (Tschumi, 2017, 196). Daha sonra sinemadaki bedenin zamana odaklı eylemlerinin peşinden giden Tschumi; bu anlatımı kendine has, yeni mimari birleşim kodlarıyla harmanlıyor. Film kurgusunda sekansların sıralanması, müzik, görsel filtreler, renkler, şekiller, yazılar; alt alta eklenen, çakışan ama çakışmalarından yeni bir şey türeten anlatımıyla sinema, Tschumi'ye yeni bir birleşim kodu sunuyor. Eisenstein' in ilk sesli filmi olan Alexander Nevsky'nin (Sergei Eisenstein \& Dmitri Vasilyev, 1938) kurgusunda kullandığı, görsel ve işitsel malzemelerin keskinlikle hesaplandığ 1 diyagramdan (Ek F) hareketle Tschumi; Psycho'dan (Sapık, Alfred Hitchcock, 1960) aldı̆̆ı görüntüleri, mimari bir kurgu haline getirir (Ek G).

Sekanslar bölümünde mekan sekansları kavramını tanımlayan Tschumi, bu sekansların yüzyıllardır süregelen özgül mekan örgütlenmeleri olduğunu söyler. Sabit duraklardan oluşan ve kesintisiz bir biçimde birbirine bağlanan mekanlar, planlanmış bir örgütlenmeyi vurgular. Karışık biçimsel düzenlemeler sergilese dahi, mekânsal sekanslar bir örgütlenmeye tabiidir. Olay sekansları, kullanım ve etkinlikler; sabit olan mekânsal sekanslarda üst üste bindirilmiştir. Her mekanın doğası gereği sahip olduğu ve önceden planlanan programı ise mekan dâhilindeki olaylar, hareketler, icralar sistemi olarak tanımlayan Tschumi; programları üç temel kategoriye ayırır: Mekansal sekanslara kayıtsız kalanlar, mekânsal sekansı güçlendirenler ve çaprazlama. Kayıtsızlık söz konusu olduğunda mekansal sekanslar ve olay sekansları birbirinden bağımsızdır. Mekan ve olay birbirine tamamen kayıtsızdır, faydacı kaygılar gütmemektedir. Tschumi bu duruma, bir taburun arazide ilerlemesini örnek gösterir. Mekansal sekansı güçlendiren programlarda ise bir karşılıklılık görürüz. Mekan ve olay sekansları, birbirlerinin var oluşunun koşuludur ve birbirlerine bağlıdırlar. Sekansların her biri, birbirini destekler; Tschumi bu duruma ise patencilerin paten sahasinda paten yapıyor olmasını örnek gösterir. Çatışmada ise mekansal sekanslar ve olay sekansları 
tamamen birbirinin aleyhine çalışır. Birbiriyle çarpışan ve çelişen sekanslar, sürekli bir çatışma halinde diğerinin kurallarına karşı çıkar ve kendi kurallarını dayatır. Tschumi bu duruma da bir taburun gergin bir ipte paten yapmasını örnek gösterir (Tschumi, 2017, s.201 - 211). The Square'de (Kare, Ruben Östlund, 2017) gördüğümüz daveyemeği sekans1, mekansal sekansa kayıtsız kalan bir programla başlar. Altın işlemeli ve sütunlarla çevrili salondaki masalarda yemek yenmektedir. Biçim ve kullanım arasında bir koşul ya da bir çatışma görülmemektedir. Devam eden sahnede duyulan, “Ormana hoşgeldiniz... Hareketsiz kalırsan sürünün içinde saklanırsın ve hayvan sana bir şey yapmaz" anonsu ve duyulan kuş sesleri; içinde bulunulan şatafatlı mekan ve doğa arasında bir koşul ilişkisi yaratmaktadır. Steril takım elbiselere bürünmüş mekanın içine giren hayvan, tüm "post modern" duruşunu bu sterilliğe borçludur ve program, mekansal sekansı güçlendirmektedir. Doğru yemek için doğru çatal ve biçağın farz olduğu masalar arasında dört ayak üzerinde dolaşan hayvanın tezatlığı; ona gülünmesi, merak duyulması ve bir performans olarak izlenmesi için temel koşuldur. Bir zaman sonra mekan ve olay çatışması başlar. Onunla alay eden ve şakalaşan adama sinirlenen hayvan, onunla güç yarışına girer ve kazanır. Herkesin başını öne eğip sürünün içinde fark edilmemeye çalıştığı anlarda; mekansal sekans ve olay sekansı birbirlerini ihlal eder. Parlak porselenlerin süslediği masaya zıplayan hayvan, bir kadına yönelir ve ona dokunmaya başlar. Güçlü ve kendinden emin bir şekilde kapıdan içeri girenler; olay sekansının dayatmalarıyla bir davet salonundan, adaptasyonu güçlü olanın hayatta kaldığı bir ormana dönüşen mekanda çıt bile çıkarmaz. Kadını yerde sürüklemeye ve ardından saldırmaya başlayan hayvana artık tepki veren davetliler; vahşi bir sürü gibi, yalnız hayvana saldırır. Mekan, yaşanan kopma sonucunda davet salonundan cinayet mahalline dönüşür. Fakat paylaşılan suç, suçluyu yok eder.

Mimarlık ve Kopma (Tschumi, 2017), Tschumi'nin mimariyi özgürleştirme ve salt bir nesne olmaktan kurtarma çalışmalarıdır. Modern dünyanın her alanında yaşadığımız kopmaları ve yabancılaşmayı, içinde bedenlerimizin olduğu mekanlarda deneyimlemek ve anlamlandırmak ise mekan ile aramızdaki sınırları ve kavgayı görmeyi sağlamaktadır. Mekanın bir şiddet aktörü olarak varlığı üzerine düşünmek, mimari ile sinemanın girift ilişkisi bağlamında ufuk açmaktadır.

\section{EKLER}

\section{EK A: Pruitt-Igoe Projesi}

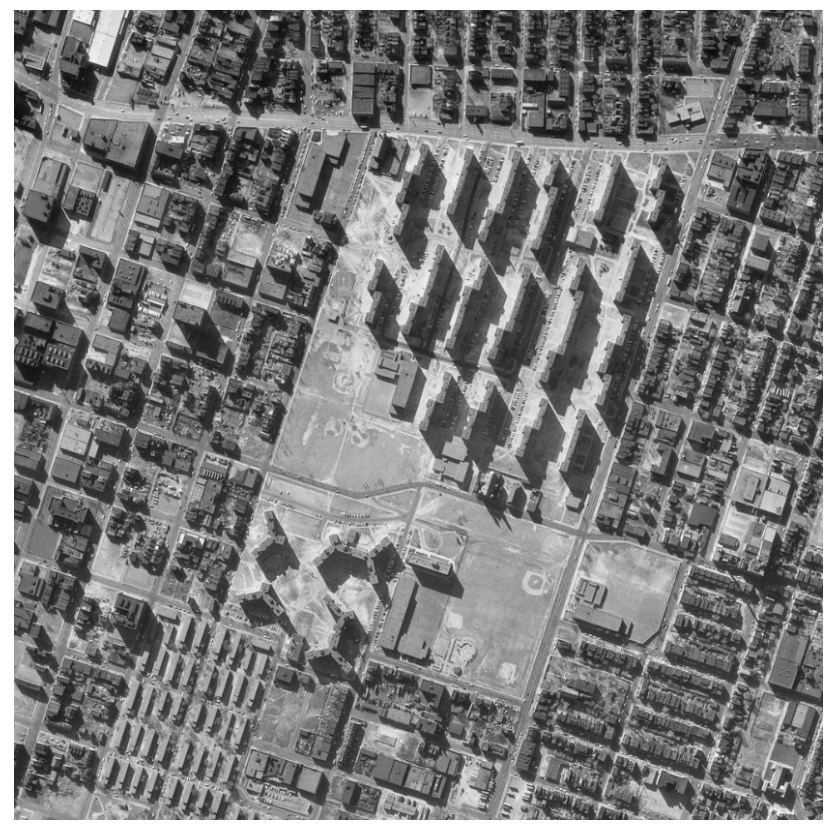

Kaynak: https://www.archdaily.com/870685/ad-classics-pruitt-igoe-housing-project-minoru-yamasaki-st- 


\section{EK B: Pruitt-Igoe Projesi Yıkımı}

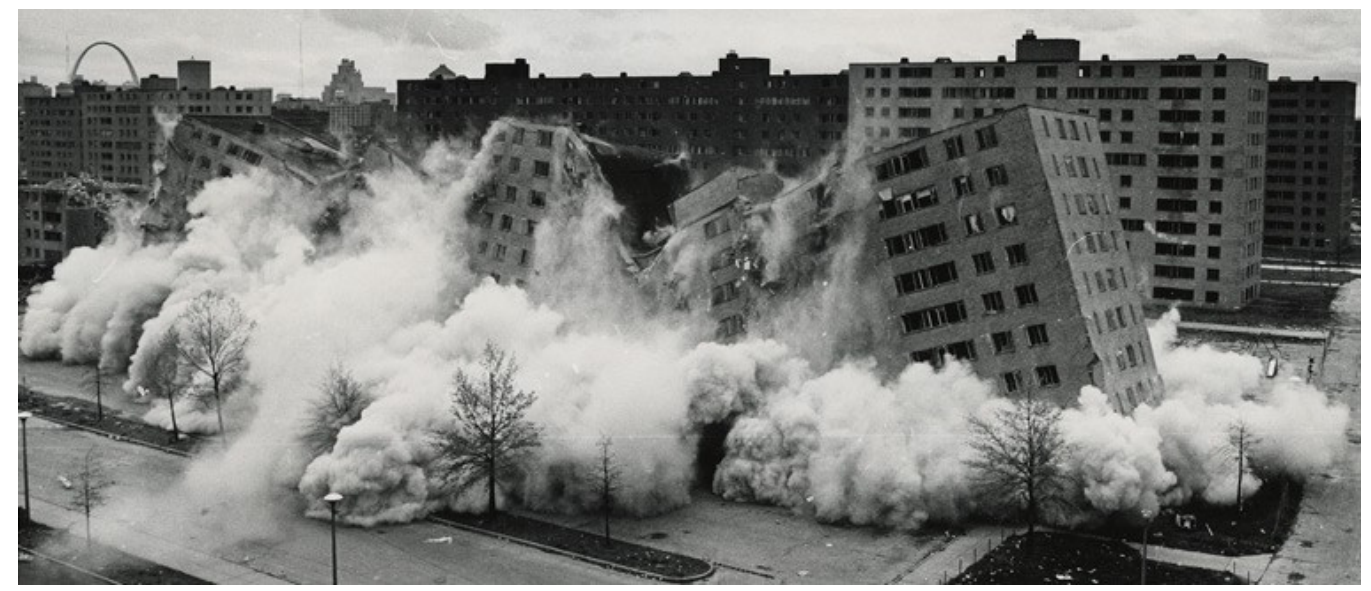

Kaynak:: https://www.huduser.gov/portal/pdredge/pdr_edge_featd_article_110314.html.

Ulaşım Tarihi: 17.04 .2021

\section{EK C: Tschumi Mimarlık Reklamları}

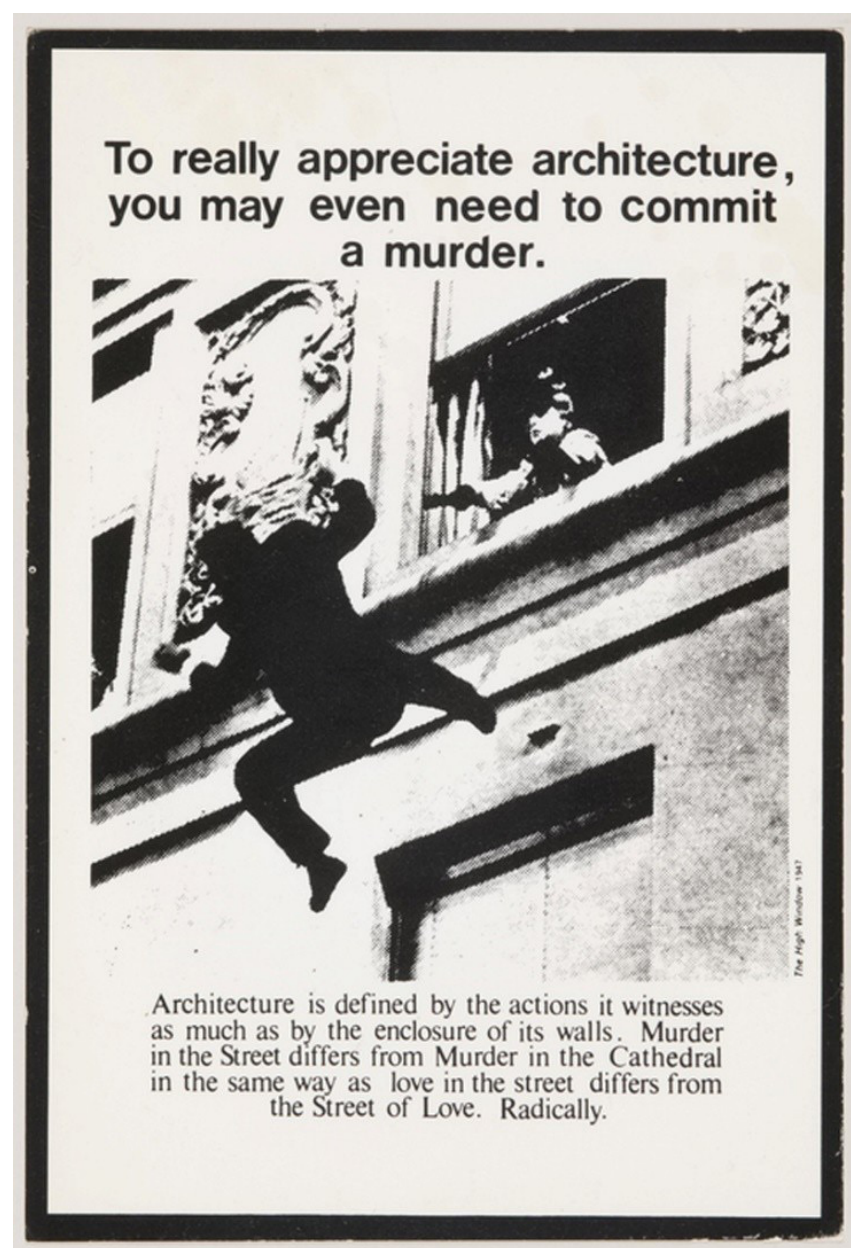

Kaynak:: https:/ /www.we-find-wildness.com/2010/12/bernard-tschumi-advertisements-for-architecture/. 
EK D: Repulsion, Koridordaki Eller
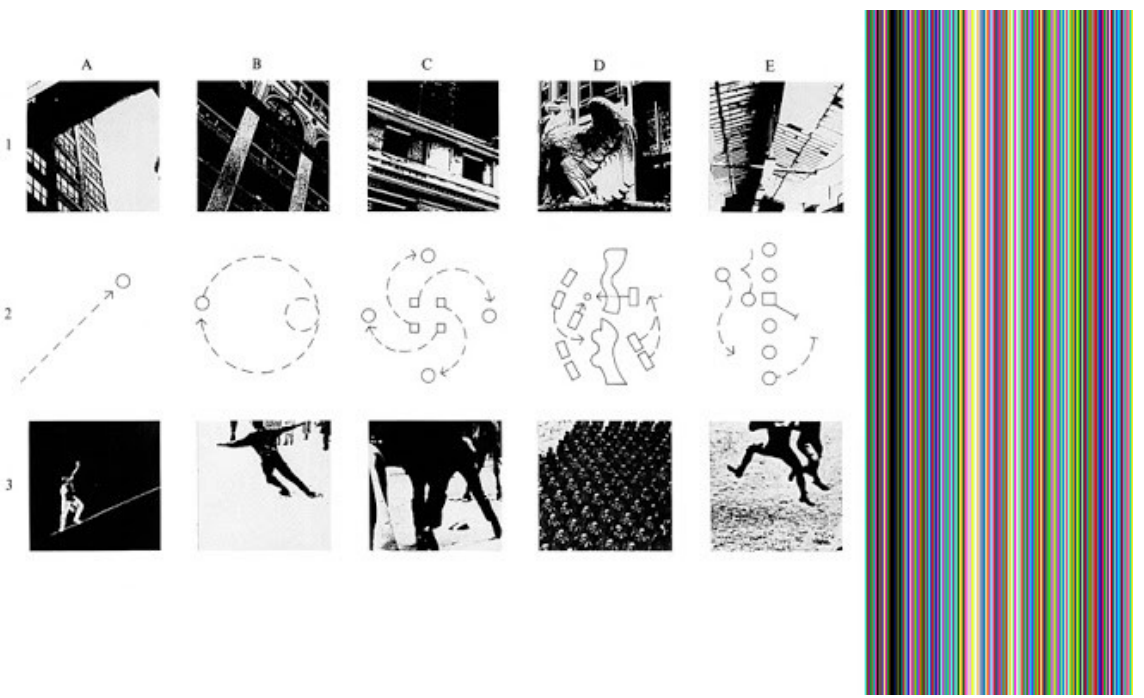

Kaynak: https:/ / scariesthings.com/2019/02/10/erics-review-repulsion-1965. Ulaşım Tarihi: 18.04.2021

EK E: Tschumi, Manhattan Transkriptleri Örneği
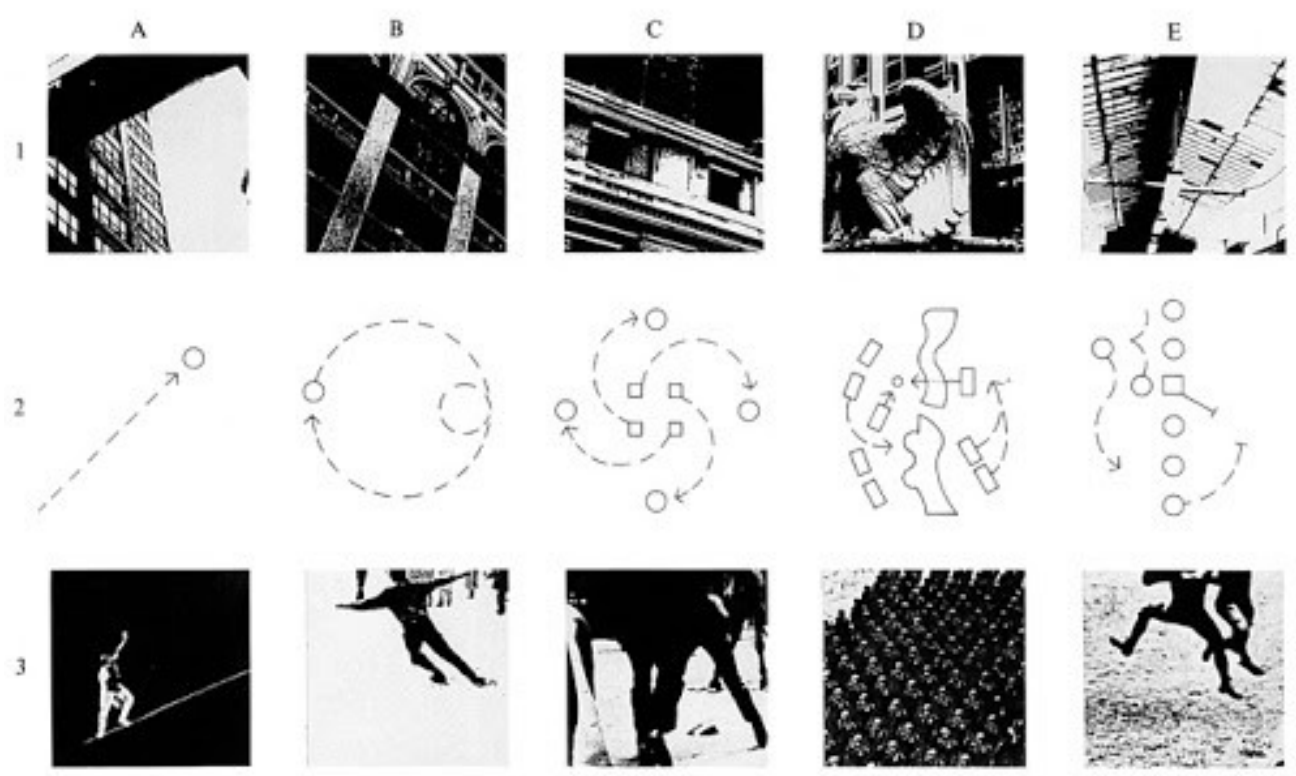

Kaynak: http:/ / www.tschumi.com/projects/18/\#. Ulaşım Tarihi: 22.04.2021. 


\section{EK F: Sergei Eisenstein, Alexander Nevsky Kurgu}
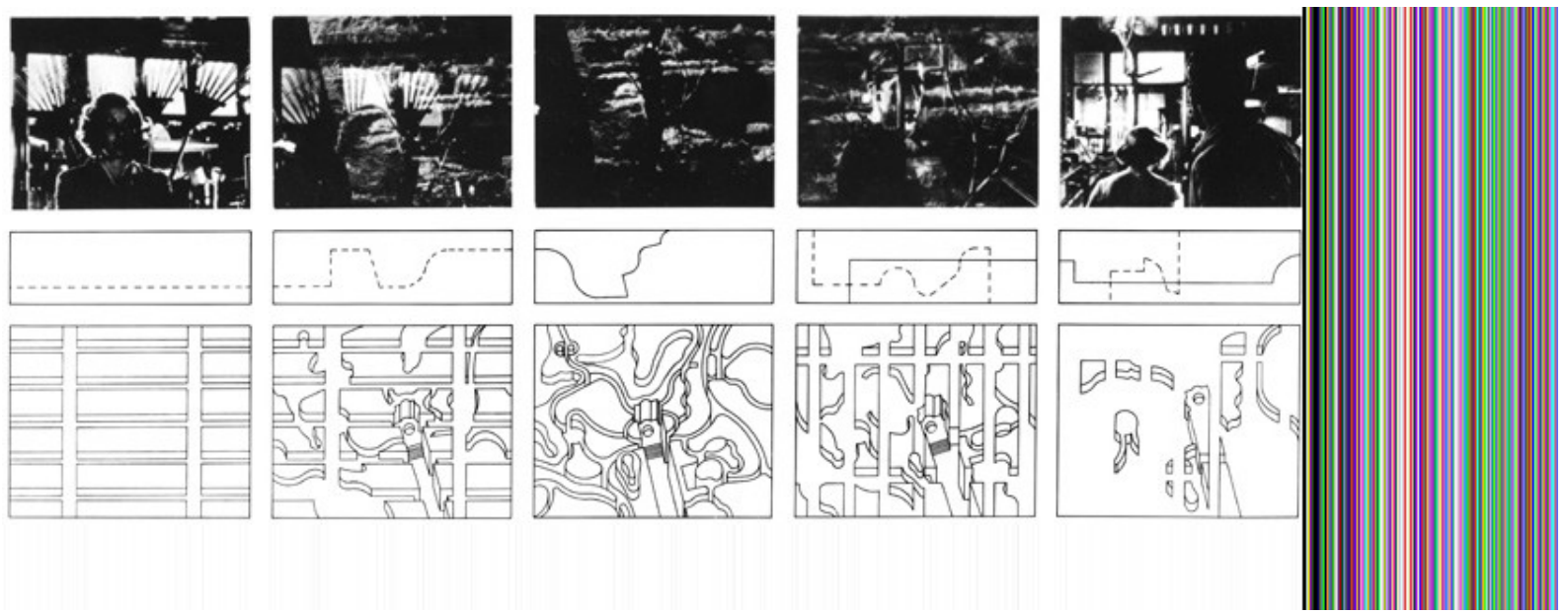

Kaynak: https://engagger.wordpress.com/2016/12/31/sergei-eisenstein-alexander-nevsky/.

Ulaşım Tarihi: 22.04.2021

\section{EK G: Tschumi, Psycho}
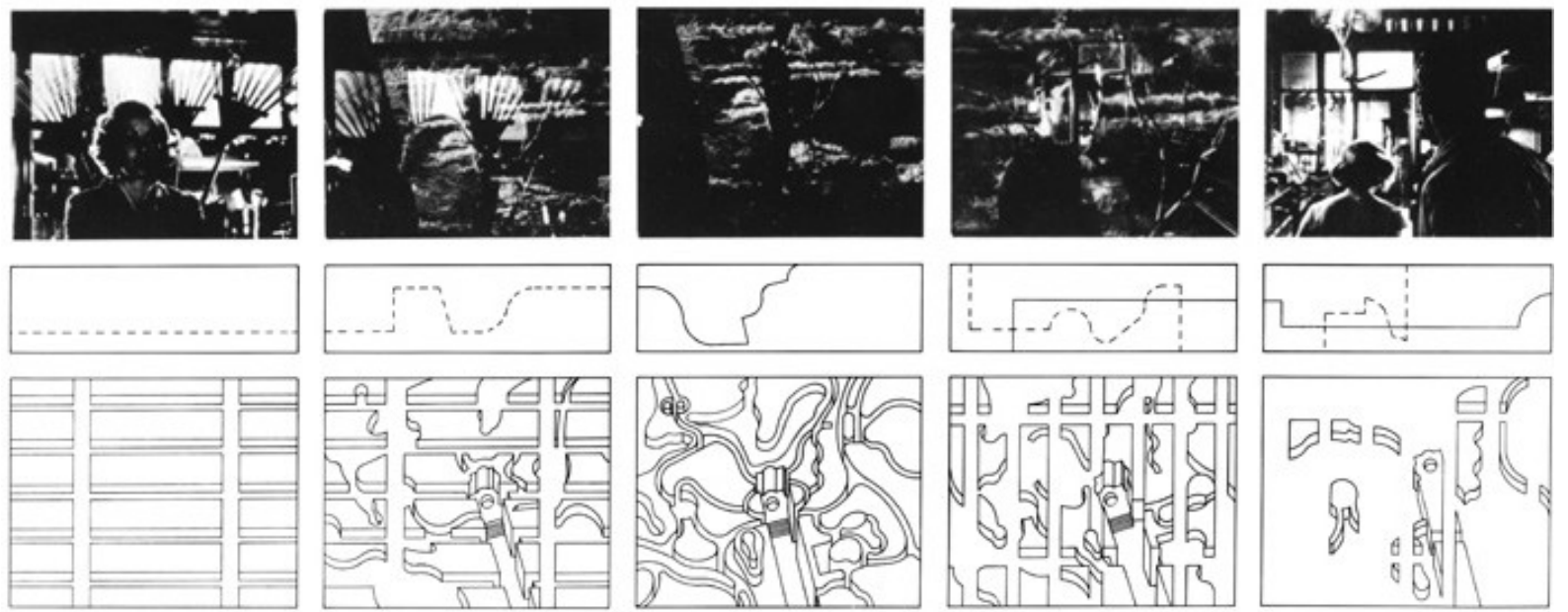

Kaynak: https://www.wordsinspace.net/media-architecture/2012-spring/?p=482. Ulaşım Tarihi: 22.04.2021 


\section{Kaynakça}

Akdeniz, N. \& Esmer, T. \& Esmer, P (Yapımc1) \& Esmer, P. (Yönetmen). (2012). Gözetleme Kulesi (Sinema Filmi). Türkiye: Tiglon.

Barbarash, E \& Block, P. \& Colvin, S. (Yapımc1), \& Sekuła, A. (Yönetmen). (2002). Cube 2: Hypercube (Sinema Filmi). Canada: Lions Gate Films.

Castle, V. (Yapımcı), \& Polanski, R. (Yönetmen). (1968). Rosemary's Baby (Sinema Filmi). ABD: Paramount Pictures.

Elliott, A. \& Gentles, M. \& Milchan, A. \& King, E \& Lee, R. (Yapımc1) \& Weekes, R. (Yönetmen). (2020). His House (Sinema Filmi). ABD: Netflix.

Eisenstein, S. \& Vasilyev, D. (Yönetmen). (1938). Alexander Nevsky (Sinema Filmi). Sovyetler Birliği: Mosfilm.

Goulding, S. \& Goulding, J. (Yapımc1), \& Barbarash, E. (Yönetmen). (2004). Cube Zero (Sinema Filmi). Canada: Lions Gate Entertainment.

Gutowski, G. (Yapımc1), \& Polanski, R. (Yönetmen). (1965). Repulsion (Sinema Filmi).

İngiltere: Compton Films.

Hemmendorff, E. \& Bober, P. (Yapımc1) \& Östlund, R. (Yönetmen). (2017). The Square (Sinema Filmi). İsveç: TriArt Film \& Almanya: Alamode Filmverleih \& Fransa: BAC Films \& Danimarka: Scanbox Entertainment.

Hitchcock, A. \& Reville, A. (Yapımc1) \& Hitchcock, A. (Yönetmen). (1960). Psycho (Sinema Filmi). ABD: Paramount Pictures.

https:// www.archdaily.com/870685/ad-classics-pruitt-igoe-housing-project-minoruyamasaki-st-louis-usa-modernism

https://www.huduser.gov/portal/pdredge/pdr_edge_featd_article_110314.html

https:/ / www.we-find-wildness.com/2010/12/ bernard-tschumi-advertisements-forarchitecture/

http://www.tschumi.com/projects/18/\# com/2016/12/31/sergei-eisenstein-alexander-nevsky/ media-architecture/2012-spring/?p=482

https:/ / engagger.wordpress.

Koyuncu, P. (2011). “Modern Mimarlı̆̆ın Öldüğü G ü n ”. Erişim Adresi: https://www.arkitera.com/haber/modern-mimarligin-oldugu-gun/

Meh, M. \& Orr, B. (Yapımc1), \& Natali, V. (Yönetmen). (1997). Cube (Sinema Filmi). Canada: Trimark Pictures.

Pressman, E. (Yapımc1), \& Ferrara, A. (Yönetmen). (1992). Bad Lieutenant (Sinema Filmi). ABD: Aries Films.

Stanley, K. (Yapımc1) \& (Yönetmen). (1980). The Shining (Sinema Filmi). ABD: Warner Bros. Tschumi, B. (2017). Mimarlık ve Kopma, İstanbul: Janus Yayıncılık.

Varda, A. \& JR. (Yönetmen). (2017). Visages Villages (Sinema Filmi). Fransa: Le Pacte.

Zarchi, M. (Yapımc1), \& Zarchi, M. (Yönetmen). (1978). I Spit on Your Grave (Sinema Filmi). ABD: Cinemagic Pictures. 
- Söyleşiler.Interviews -

\title{
Hakan Aytekin'le Söyleşi
}

\author{
Kurtuluş Özgen \\ Işkın Özbulduk Kılıç
}

\begin{abstract}
Kurtuluş Özgen: Sinefilozofi dergisinin yönetmen söyleşilerinin bugünkü konuğu yönetmen ve yazar Hakan Aytekin. Dilerseniz hemen ilk soruyla başlayayım Hakan Bey. Suha Arın ekolünün önde gelen temsilcilerinden birisiniz. 'Kültürel Hümanizma' bu sizin dönemini tanımlayan tanımınız, sizin de böyle bir döneminiz olduğunu düşünüyorum. Tarihi ve kültürel konuları ele alan çok sayıda belgesel ürettiniz. Bu çalışmalarınız Türkiye' deki tarihi ve kültürel koruma politikalarının oluşmasına önemli katkılar yaptı. Suha Arın ekolünün en önemli özelliği filmlerin omurgasını bilgi ve belgeyle özellikle akademik bilgiyle inşa etmesi. Bilgi, belge ve belgesel sinema arasında size göre nasıl bir ilişki var?
\end{abstract}

Hakan Aytekin: Bilgisiz ve belgesiz belgesel sinemanın yapılabileceğine inanmıyorum. Çünkü belgesel sinema daha kavramın kendisine içkin olarak belgeden söz eden bir sinema. Belge dediğimiz şey içinde bilgiyi barındıran bir şeydir. Çünkü o bir bilginin toplamda bir araya getirildiği onu ifade eden ya da onu temsil eden bir materyal ya da bir durum, bir olaydır. Bu bağlamda bilgiyi belgeden, belgeyi belgesel sinemadan koparmak çok mümkün değil. Ancak şöyle bir durum var. Son yillarda benim kültürel hümanizma olarak ifade ettiğim dünyadaki değişik belgesel sinema kuramcılarının da özellikle açıklayıcı ya da didaktik noktada ifade ettikleri filmlerde aslında çok yoğun bir şekilde bir bilginin aktarımı söz konusu. Ve bu bilgi daha çok akademik bilgiye yakın olarak ifade ediliyor. Bunun farklı nedenleri var. Belgesel sinema tarihi içinde üstlendiği işlevden belgesel sinemaya gerçekleştirmek için gerekli olan donanıma varana kadar pek çok unsur bizi, açıklayıcı ya da didaktik olmaya zorunlu kılmıştır. Bugünkü belgeselcilerin ya da belgesel üzerine yazanların şöyle bir ön kabulü var gibi geliyor bana. Sanki ses ve ses kaydı belgesel sinema başladı̆̆ından bu yana mümkündü ve belgesel sinemacılar tercihen sesi kullanmadılar gibi ben yer yer böyle tuhaf açıklamalara rastlıyorum. Ama bu bir teknolojiyle gelişen alanda ses kaydının mümkün olmasıyla erişebilen bir durum. Oysa benim belgesel sinemaya başladığım ve sizin sorularınızda yer alan Suha Arın ekolünün belgesel sinemayla hemhal olduğu dönemlerde ses ne yazık ki alanda sınırlı ölçüde eş zamanlı olarak kaydedilebilen ve kullanılan bir şeydi. Ekipte her şeyden önce pelikül kullanılıyordu. Pelikülde ses kaydı yoktur. Sesi ayrıca kaydedersiniz ve stüdyo aşamasında yani laboratuvar aşamasında pek çok aşama geçtikten sonra o ses filme ancak eşlik edebilir. Hal böyle olunca sizin alandan da anlatmak istediğiniz her şeyi doğrudan kaynak kişi aracılığı ile kaydetmeniz ve aktarmanız imkânsız. Bunu doğal olarak stüdyo aşamasına aktarmak zorundasınız. Ve o zamana kadar da belgesel sinemanın doğuşundan itibaren o hayatı anlama tanımlama gibi kaygıları olduğu içinde o bilgiyle ve anlatılanın çok uzun yıllar bize çok yanlış yere götüren nesnellik kavramına dayanma kaygısının da yarattığı bir şekilde bilgi o anlamda akademikleşti. Ve ister istemez daha çok yönetmenin sözünün olduğu bir form bu didaktik form... Baktığımızda katılımcı ya da refleksif belgeselde daha çok varlığı filan tartışılıyor. Ama bu bana göre varsayımsal bir şey. Doğru bulmuyorum. Asıl yönetmenin varlığı açıklayıcı didaktik filmlerde tanrının sesi diye bugün aşağılanan şey, yönetmenin kendi bilgisi. Ya da gerçekliği algılama biçimi. Bunu kabul edebiliriz, etmeyiz. Çok tartışmalara girmek istemiyorum. Çünkü bugünkü belgesel sinema modlarına da karş1 değilim. Ve ben bugünkü modlarda film üretmeye çalışıyorum ama gerçek çok tanımlanabilir bir şey değil. Yani bunu nasıl aktaracaksınız. Siz ancak gerçekliğin bilgisini aktarabilirsiniz. Bakın üzerine basarak söylüyorum. Gerçekliği değil gerçekliğin bilgisini aktarabilirsin. Bu bilginin de akademik bilgiyle örtüşmesi kadar doğal hiçbir şey olamaz. Bu bağlamda Suha 